\title{
Variations in the Torg-Pavlov Cervical Ratio with Regard to Age and Sex. A Comprehensive Anatomical and Morphometric Study on Contemporary Cadaveric Specimens
}

\author{
Variaciones en el Índice de Torg-Pavlov Cervical Respecto a Edad y Sexo. \\ Un Exhaustivo Estudio Anatómico en una Población Contemporánea
}

\begin{abstract}
Rodolfo Morales-Avalos ${ }^{1,2}$; Brenda Martínez-González²; Francisco Ismael Villarreal-Garcia'; Priscila Madelein RequenaAraujo; ; Oscar Armando Martínez-Gutiérrezi ${ }^{1}$ Pedro Martín Reyes-Fernández ${ }^{1}$; Víctor Manuel Peña-Martínez ${ }^{1}$; Gabriela Sánchez-Mejorada ${ }^{3}$; Félix Vílchez-Cavazos ${ }^{1}$; Santos Guzmán-López ${ }^{2}$ \& Rodrigo E. Elizondo-Omaña ${ }^{2}$
\end{abstract}

MORALES-AVALOS, R.; MARTÍNEZ-GONZÁLEZ, B.; VILLARREAL-GARCIA, F. I.; REQUENA-ARAUJO, P. M.; MARTÍNEZ-GUTIÉRREZ, O. A.; REYES-FERNÁNDEZ, P. M.; PEÑA-MARTÍNEZ, V. M.; SÁNCHEZ-MEJORADA, G.; VÍLCHEZ-CAVAZOS, F; GUZMÁN-LÓPEZ, S. \& ELIZONDO-OMAÑA, R. E. Variations in the Torg-Pavlov Cervical Ratio with regard to age and sex. a comprehensive anatomical and morphometric study on contemporary cadaveric specimens. Int. J. Morphol., 36(2):598-607, 2018.

SUMMARY: The Torg-Pavlov ratio is a method used to detect cervical stenosis. A Torg-Pavlov ratio $\leq 0.80$ suggests significant stenosis. This ratio is obtained by dividing the anteroposterior diameter of the cervical canal by the anteroposterior diameter of the vertebral body. The aim of this study was to evaluate these parameters and determine if there are significant differences with respect to sex and age. This is an anatomical and comparative study in which 1020 cervical vertebrae from C2-C7 from an osteological collection were evaluated. We determined the anteroposterior diameter from the vertebral body, the anteroposterior diameter from the vertebral canal and the Torg-Pavlov ratio. The pieces studied were divided into groups according to sex and age, resulting in six groups of study. A statistical analysis was made to determine the significance of the differences between sex and age groups. The size of the vertebral body diminished form C2-C3 and increased from C4-C7. The canal diminished form C2-C4 and increased from C5-C7. The Torg-Pavlov ratio decreased from $\mathrm{C} 2-\mathrm{C} 7$. The body and the canal were higher in men, while the Torg-Pavlov ratio was higher in women. With age, in men, the size of the body increased, the canal maintained its size, and the Torg-Pavlov ratio diminished significantly. In the group of women $\geq 60$ years, the size of the body decreased, and the canal and the Torg-Pavlov ratio increased. In men, the Torg-Pavlov ratio is determined by the vertebral body and canal, because these did not show differences in most of the age groups. While in women, it is determined mostly by the spinal canal because it presented more variability between the age groups.

KEY WORDS: Cervical stenosis; Cervical vertebrae; Spinal canal; Age groups; Sex.

\section{INTRODUCCIÓN}

The size of the cervical vertebral canal has clinical relevance in trauma and degenerative conditions of the spine (Matveeva et al., 2013). It has been shown that greater canal diameters reduce the probability of neurological damage secondary to fractures or dislocation of the cervical spine (Dean et al., 2007). Cervical canal stenosis is a major risk factor for the onset and severity of neurological damage secondary to cervical trauma, furthermore, is involved in the development of myelopathy and radiculopathy (Dean $e t$ al.).
Pavlov et al. (1987) proposed a method for detecting cervical stenosis called the "Torg-Pavlov ratio" (Aebli et al., 2013; Pavlov et al.). This ratio is obtained by dividing the AP diameter of the cervical canal by the AP diameter of the vertebral body using conventional lateral cervical spine x-rays (Pavlov et al.; Aebli et al.; Castro, 2003; Dean et al.). A result equal or less than 0.80 is accepted as an indicator of significant cervical stenosis (Tierney et al., 2002; Lim \& Wong, 2004; Tatarek, 2005; Tjahjadi \&

\footnotetext{
${ }^{1}$ Orthopedics and Traumatology Service, Hospital Universitario “Dr. José Eleuterio González”, School of Medicine, Universidad Autonóma de Nuevo León, Monterrey, Nuevo León, México.

${ }^{2}$ Department of Human Anatomy, School of Medicine, Universidad Autonóma de Nuevo León (U.A.N.L.), Monterrey, Nuevo León, México.

${ }^{3}$ Laboratory of Physical Anthropology, Department of Anatomy, School of Medicine, Universidad Nacional Autonóma de México (U.N.A.M.), México City, México.
} 
MORALES-AVALOS, R.; MARTÍNEZ-GONZÁLEZ, B; VILLARREAL-GARCIA, F, I;; REQUENA-ARAUJO, P. M.; MARTÍNEZ-GUTIÉRREZ, O. A.; REYES-FERNÁNDEZ, P. M.; PEÑA-MARTÍNEZ, V. M.; SÁNCHEZ-MEJORADA, G.; VÍLCHEZ-CAVAZOS, F.; GUZMÁN-LÓPEZ, S. \& ELIZONDO-OMAÑA, R. E. Variations in the Torg-Pavlov Cervical Ratio with regard to age and sex. a comprehensive anatomical and morphometric study on contemporary cadaveric specimens. Int. J. Morphol., 36(2):598-607, 2018.

Onibala, 2010; Matveeva et al.) and a ratio greater than or equal to 1.0 indicates no canal stenosis (Tjahjadi \& Onibala).

Although numerous studies have assessed the validity of using the Torg-Pavlov ratio to predict spinal injury, few have quantified the incidence of asymptomatic cervical stenosis based on this method (Dean et al.). Most studies that compare differences in the cervical canal use $\mathrm{x}$-rays, CT scans, and MRI in patients with cervical trauma without significant bone or ligamentous alteration. Few have examined cadaveric bone specimens without the presence of tissue to determine variations in dimensions (Tatarek). These studies used small samples that belonged to historical bone collections that lacked information on age and sex. Direct measurements in cadavers provide a more accurate assessment of the canal (Dean et al.).

On the other hand, it has been reported that the TorgPavlov ratio differs widely between sexes within the same race or ethnic group (Dean et al.; Lim \& Wong) and decreases with bone growth (Castro). This information will avoid misdiagnosis of a narrow canal and will help predict and detect patients with an elevated risk of developing temporary or permanent nerve complications after cervical trauma.

That is why the objective of this study is to determine a range of normal values for the AP diameter of the vertebral body, the AP diameter of the vertebral canal and the TorgPavlov ratio in each cervical vertebral level (C2-C7) in Mexican population using direct measurement of osteological specimens and determine whether there are significant differences between these parameters with respect to sex and age.

\section{MATERIAL AND METHOD}

This is an anatomical, observational, cross-sectional, descriptive, and comparative study of 1020 cervical vertebrae from levels $\mathrm{C} 2$ to $\mathrm{C} 7$ from 170 dry cervical spines, belonging to an osteological collection of contemporary Mexican population. This collection had medical information of each cadaver including sex and age. We include normal cervical spines with an age range between 18 and 99 years ( 64 females and 104 males). Specimens with structural anomalies or abnormalities in their vertebral morphology and with history of neurological diseases of the cervical spine were excluded.

The pieces studied were divided into groups according to sex and in turn were subdivided into three subgroups according to age with the following ranges: 1839 years, $40-59$ years and $\geq 60$ years, resulting in six groups of study (Table I). This division was based on the degenerative patterns that occur in the spine with age (Morales-Avalos et al., 2013).

A millimetric digital Vernier with a precision of 0.01 mm (Mitutoyo w/AbsoluteEncoders Series 500) was used for each of the specimens to perform the following measurements bilaterally (Fig. 1).

Table I. Number of cervical spines in each group according to sex and age.

\begin{tabular}{ccccc}
\hline \multirow{2}{*}{ Sex } & \multicolumn{3}{c}{ Age range (years) } & \multirow{2}{*}{ Total } \\
\cline { 2 - 4 } & $18-39$ & $40-59$ & $\geq 60$ & \\
\hline Women & 23 & 19 & 22 & 64 \\
Men & 35 & 36 & 35 & 106 \\
Total & 58 & 55 & 57 & 170 \\
\hline
\end{tabular}
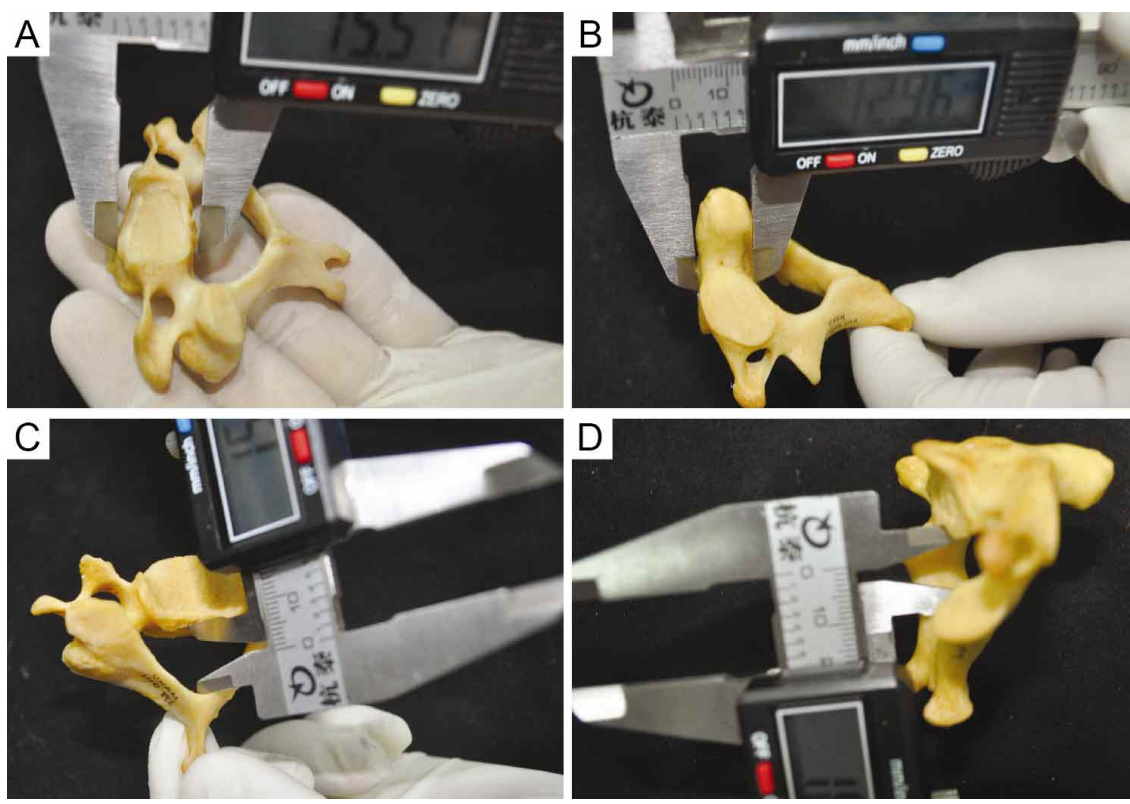

Fig. 1. Representative photograph of the measurement technique of the cervical vertebrae.

A. Anteroposterior diameter of the vertebral body $\mathrm{C} 3$ to $\mathrm{C} 7$. B. Anteroposterior diameter of the vertebral body $\mathrm{C} 2$. C. Anteroposterior diameter of the vertebral canal of C3 to C7. D. Anteroposterior diameter of the vertebral canal of $\mathrm{C} 2$. 
MORALES-AVALOS, R.; MARTÍNEZ-GONZÁLEZ, B.; VILLARREAL-GARCIA, F. I.; REQUENA-ARAUJO, P. M.; MARTÍNEZ-GUTIÉRREZ, O. A.; REYES-FERNÁNDEZ, P. M.; PEÑA-MARTÍNEZ, V. M.; SÁNCHEZ-MEJORADA, G.; VÍLCHEZ-CAVAZOS, F.; GUZMÁN-LÓPEZ, S. \& ELIZONDO-OMAÑA, R. E. Variations in the Torg-Pavlov Cervical Ratio with regard to age and sex. a comprehensive anatomical and morphometric study on contemporary cadaveric specimens. Int. J. Morphol., 36(2):598-607, 2018.

1. AP diameter of the vertebral body. Distance between the anterior border and the posterior border of the vertebral body at the midline on the upper surface of the vertebra (Figure 1a). In the case of $\mathrm{C} 2$ the measurement was performed on the lower border (Fig. 1b).

2. AP diameter of the vertebral canal. Distance between the posterior border of the vertebral body and the posterior border of the spinal canal at the level of the midline (junction between two vertebral laminae) (Fig. 1c). In the case of C2 the measurement was made on the lower border (Fig. 1d).

3. The Torg-Pavlov ratio. Was digitally calculated from the previous two measurements to obtain the ratio between the AP diameter of the vertebral canal and the AP diameter of the vertebral body.

All measurements were reported in centimeters and stored in a database for subsequent statistical analysis.

Statistical analysis. The statistical analysis was performed using Microsoft Excel ${ }^{\circledR} 2013$ for Windows XP. Prior to the start of the study, a subsample of osteological specimens made up of 30 cervical spines ( 15 male and 15 female) were randomly selected to standardize the measurement technique and perform intraobserver variation statistical tests. Two measurements were made by the same observer and a twotailed Student's t test was applied to determine the significance of variations between the two measurements, interpreting a $\mathrm{p}$ value $<0.05$ as significant.
For each of the six groups, the mean and standard deviation for each measurement parameter were determined independently. A two-tailed Student's t test was used to determine the significance of differences between the mean of each of the three morphometric parameters independently for men and women for each vertebral level and corresponding age group, interpreting a $p$ value $<0.05$ as significant. In the same way, a one-tailed analysis of variance (ANOVA) was performed in combination with multiple two-tailed Student's t tests to compare the different age groups of the same sex ( $18-39$ vs $40-59$; $18-39$ vs $\geq 60$; $40-59$ vs $\geq 60$ ) for each vertebral level, interpreting a p value $<0.05$ as significant.

Ethical considerations. The Ethics Committee and Research Committee of the University approved this study. No financial or commercial gain was obtained from the realization of this study; therefore, the authors declare that they have no conflict of interest.

\section{RESULTS}

Normal values for the AP diameter of the vertebral body, the AP diameter of the vertebral canal and the TorgPavlov ratio of 1020 cervical vertebrae (C2-C7) were determined. Each of these morphometric parameters and their differences regarding sex and age are presented in three sections: general and intersegmental differences, sex differences and differences in age.

Table II. Anteroposterior diameter of the vertebral body for each age group and vertebral level. Comparison between sexes.

\begin{tabular}{ccccccc}
\hline & & \multicolumn{2}{c}{ Women $(\mathrm{n}=64)$} & \multicolumn{2}{c}{ Men $(\mathrm{n}=106)$} & Women vs Men \\
\hline Vertebral level & Age range (years) & Mean $(\mathrm{mm})$ & $\mathrm{SD}(\mathrm{mm})$ & Mean $(\mathrm{mm})$ & $\mathrm{SD}(\mathrm{mm})$ & $p$ value \\
\hline C2 & $18-39$ & 14.15 & 0.87 & 15.78 & 1.17 & $<0.001^{*}$ \\
& $40-59$ & 14.43 & 1.41 & 16.30 & 1.36 & $<0.001^{*}$ \\
C3 & $\geq 60$ & 14.17 & 1.49 & 16.20 & 1.72 & $<0.001^{*}$ \\
& $18-39$ & 13.71 & 0.78 & 15.58 & 1.50 & $<0.001^{*}$ \\
& $40-59$ & 13.89 & 0.85 & 15.70 & 1.60 & $<0.001^{*}$ \\
C4 & $\geq 60$ & 13.86 & 1.22 & 15.80 & 1.46 & $<0.001^{*}$ \\
& $18-39$ & 14.03 & 0.90 & 15.68 & 1.30 & $<0.001^{*}$ \\
C5 & $40-59$ & 14.37 & 1.81 & 15.92 & 1.88 & $0.004^{*}$ \\
& $\geq 60$ & 14.26 & 0.68 & 16.27 & 2.01 & $<0.001^{*}$ \\
& $18-39$ & 14.30 & 1.12 & 16.02 & 1.71 & $<0.001^{*}$ \\
C6 & $40-59$ & 15.16 & 1.47 & 16.50 & 2.02 & $0.013^{*}$ \\
& $\geq 60$ & 14.92 & 0.72 & 16.96 & 1.78 & $<0.001^{*}$ \\
& $18-39$ & 15.08 & 1.18 & 16.74 & 1.48 & $<0.001^{*}$ \\
C7 & $40-59$ & 18.01 & 2.16 & 17.55 & 2.51 & 0.76 \\
& $\geq 60$ & 15.78 & 1.36 & 17.81 & 1.84 & $<0.001^{*}$ \\
& $18-39$ & 15.45 & 1.27 & 17.30 & 2.08 & $<0.001^{*}$ \\
& $40-59$ & 18.06 & 3.11 & 17.88 & 2.34 & 0.80 \\
& $\geq 60$ & 15.81 & 0.99 & 17.92 & 1.59 & $<0.001^{*}$
\end{tabular}

*p value $<0.05$ was considered significant. 
MORALES-AVALOS, R.; MARTÍNEZ-GONZÁLEZ, B.; VILLARREAL-GARCIA, F. I.; REQUENA-ARAUJO, P. M.; MARTÍNEZ-GUTIÉRREZ, O. A.; REYES-FERNÁNDEZ, P. M.; PEÑA-MARTíNEZ, V. M.; SÁNCHEZ-MEJORADA, G.; VíLCHEZ-CAVAZOS, F.; GUZMÁN-LÓPEZ, S. \& ELIZONDO-OMAÑA, R. E. Variations in the Torg-Pavlov Cervical Ratio with regard to age and sex. a comprehensive anatomical and morphometric study on contemporary cadaveric specimens. Int. J. Morphol., 36(2):598-607, 2018.

\section{AP diameter of the vertebral body.}

General and intersegmental differences. Table II shows the AP diameter of the vertebral bodies obtained at each level and for each age and sex. In Figure 2 is presented a graphic with the variations in the AP diameter of the vertebral body in each vertebral level by sex and age. The AP diameter of the vertebral body decreased from $\mathrm{C} 2$ to $\mathrm{C} 3$ and increased from $\mathrm{C} 4$ to $\mathrm{C} 7$ for all age groups and both sexes.

Sex Differences. Men had the highest vertebral body AP diameters compared to women in all age groups and vertebral levels (Table II). Except for the C6 and C7 levels in the group of 40-59 years, where the AP diameters were greater in women (Fig. 2).

The mean of the results for the AP diameter of the vertebral body showed significant differences $(p \leq 0.05)$ between men and women in each age group and in most of the levels studied. Only C6 $(\mathrm{p}=0.76)$ and C7 $(\mathrm{p}=0.80)$ were not significantly different between women and men 40-59 years (Table II).

Differences in age. Table III shows a comparing of the AP diameter of the vertebral bodies by age for each studied sex. In most of the age groups there were not significant differences in each vertebral level and sex. In general, in women there were more cases where the morphometric parameters differed significantly ( $\mathrm{p} \leq 0.05)$ between age groups for most of the studied vertebral levels (C5-C7) (Table III).

In men, significant differences between the groups of 18-39 years and $\geq 60$ for $\mathrm{C} 5$ and $\mathrm{C} 6$ were found, and between the age groups 18-39 and 40-59 years in C6 (Table III).

Table III. Comparison of the of the anteroposterior diameter of the vertebral bodies between age groups.

\begin{tabular}{cccc}
\hline Vertebral level & Comparison by & Women & Men \\
\hline C2 & $18-39$ vs $40-59$ & 0.46 & 0.08 \\
& $18-39$ vs $\geq 60$ & 0.96 & 0.24 \\
& $40-59$ vs $\geq 60$ & 0.54 & 0.77 \\
C3 & $18-39$ vs $40-59$ & 0.66 & 0.74 \\
& $18-39$ vs $\geq 60$ & 0.62 & 0.53 \\
& $40-59$ vs $\geq 60$ & 0.94 & 0.78 \\
C4 & $18-39$ vs $40-59$ & 0.44 & 0.54 \\
& $18-39$ vs $\geq 60$ & 0.34 & 0.14 \\
& $40-59$ vs $\geq 60$ & 0.80 & 0.44 \\
C5 & $18-39$ vs $40-59$ & $0.03^{*}$ & 0.28 \\
& $18-39$ vs $\geq 60$ & $0.03^{*}$ & $0.02^{*}$ \\
& $40-59$ vs $\geq 60$ & 0.49 & 0.31 \\
C6 & $18-39$ vs $40-59$ & $<0.001^{*}$ & $0.03^{*}$ \\
& $18-39$ vs $\geq 60$ & 0.07 & $0.004^{*}$ \\
& $40-59$ vs $\geq 60$ & $<0.001^{*}$ & 0.82 \\
C7 & $18-39$ vs $40-59$ & $<0.001^{*}$ & 0.27 \\
& $18-39$ vs $\geq 60$ & 0.29 & 0.56 \\
& $40-59$ vs $\geq 60$ & 0.002 & 0.49 \\
\hline
\end{tabular}

${ }^{*} \mathrm{p}$ value $<0.05$ was considered significant.

\section{AP DIAMETER OF THE VERTEBRAL BODY}

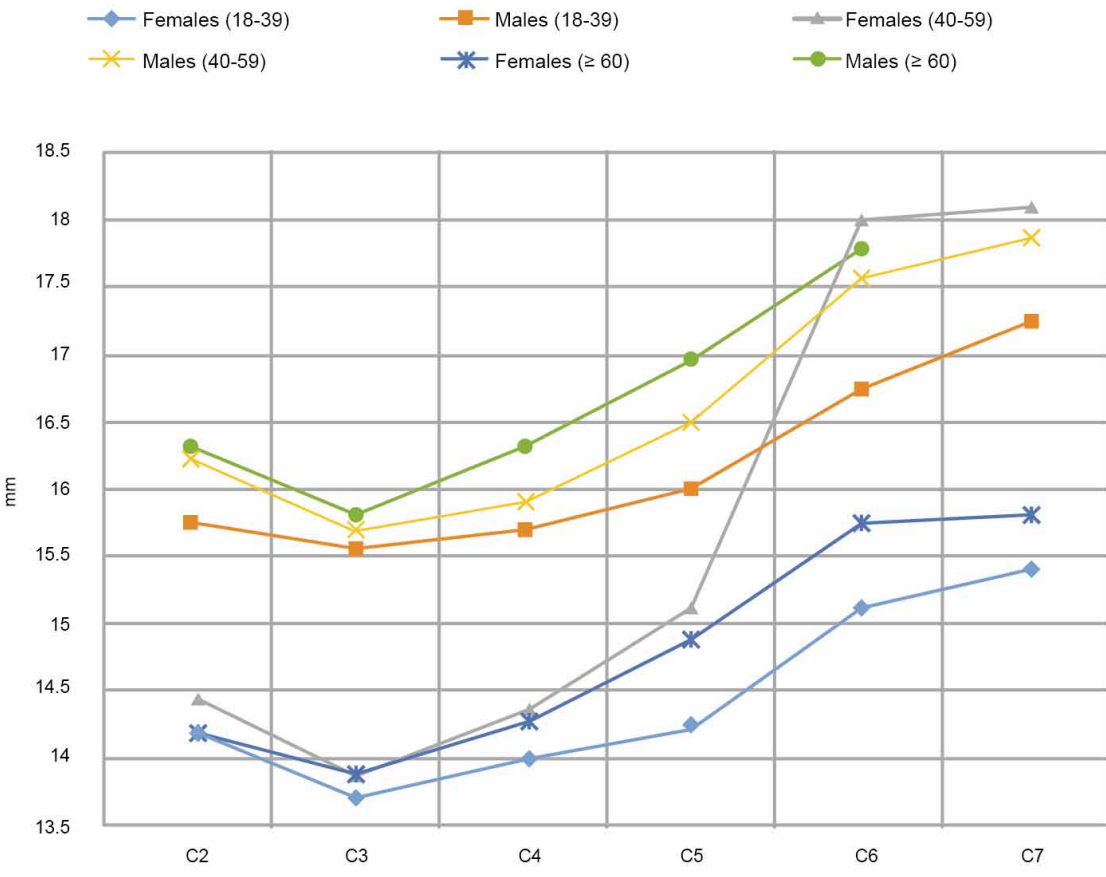

Fig. 2. Variations in the dimensions of the anteroposterior diameter of the vertebral body (C2-C7) by sex and age group. 
MORALES-AVALOS, R.; MARTÍNEZ-GONZÁLEZ, B.; VILLARREAL-GARCIA, F. I.; REQUENA-ARAUJO, P. M.; MARTÍNEZ-GUTIÉRREZ, O. A.; REYES-FERNÁNDEZ, P. M.; PEÑA-MARTÍNEZ, V. M.; SÁNCHEZ-MEJORADA, G.; VÍLCHEZ-CAVAZOS, F.; GUZMÁN-LÓPEZ, S. \& ELIZONDO-OMAÑA, R. E. Variations in the Torg-Pavlov Cervical Ratio with regard to age and sex. a comprehensive anatomical and morphometric study on contemporary cadaveric specimens. Int. J. Morphol., 36(2):598-607, 2018.

\section{AP diameter of the vertebral canal.}

General and intersegmental differences. Table IV shows the AP diameter of the vertebral canal obtained at each level and for each age and sex. In Figure 3 is presented a graphic with the variations in the AP diameter of the vertebral canal in each vertebral level by sex and age. The AP diameter of the vertebral canal showed a decrease from $\mathrm{C} 2$ to $\mathrm{C} 4$ and subsequently an increase from $\mathrm{C} 5$ to $\mathrm{C} 7$ in most age and sex groups studied.
Sex Differences. The AP diameter of the vertebral canal in general was higher in men compared to women in all age groups and at all levels studied. Except for the group $\geq 60$ years, where $\mathrm{C} 2$ to $\mathrm{C} 5$ diameters were higher in women (Fig. 3).

In women, the lowest AP diameter of the canal was observed in the 40-59 years age group in all vertebral levels. The highest diameters occurred in the age group $\geq 60$ years at all levels. In men, the behavior of the AP diameter of the ca-

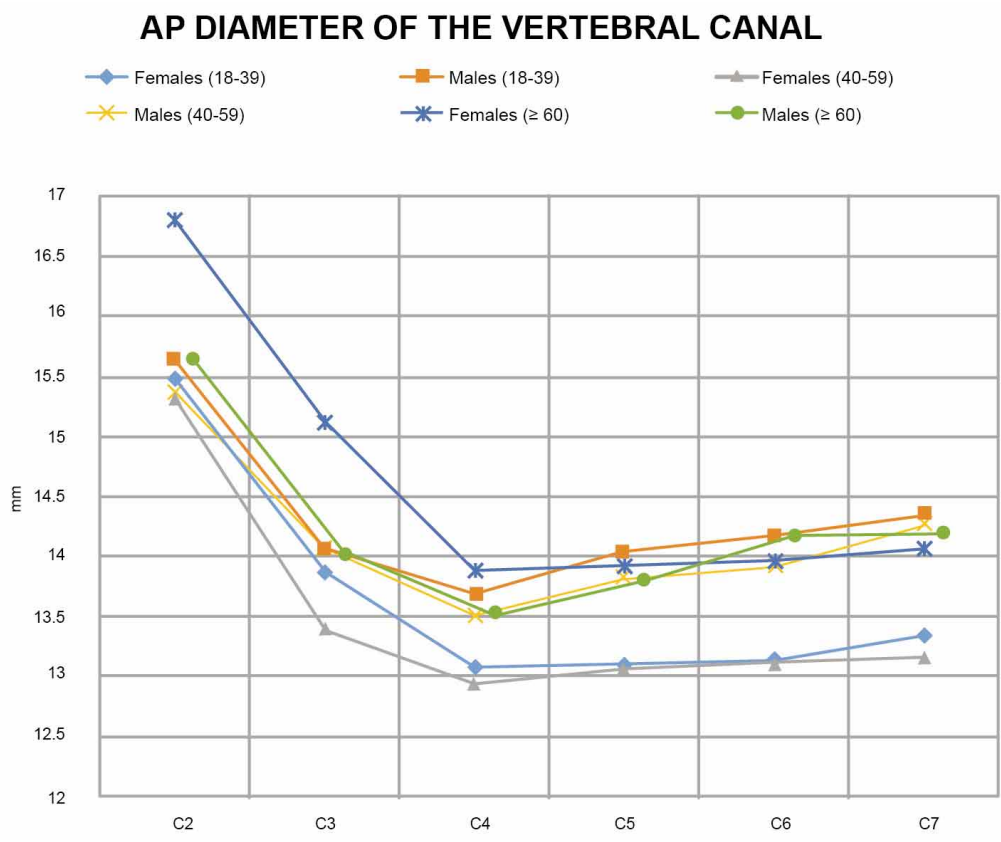

Fig. 3. Variations in the dimensions of the anteroposterior diameter of the vertebral canal (C2C7) by sex and age group.

Table IV. Anteroposterior diameter of the vertebral canal for each age group and vertebral level. Comparison between sexes.

\begin{tabular}{ccccccc}
\hline & & \multicolumn{2}{c}{ Women $(\mathrm{n}=64)$} & \multicolumn{2}{c}{ Men $(\mathrm{n}=106)$} & \multicolumn{2}{c}{ Women vs Men } \\
\hline Vertebral level & Age range (years) & Mean $(\mathrm{mm})$ & $\mathrm{SD}(\mathrm{mm})$ & Mean $(\mathrm{mm})$ & $\mathrm{SD}(\mathrm{mm})$ & $p$ value \\
\hline C2 & $18-39$ & 15.48 & 1.18 & 15.63 & 1.51 & 0.34 \\
& $40-59$ & 15.31 & 1.56 & 15.36 & 1.03 & 0.12 \\
C3 & $\geq 60$ & 16.79 & 1.65 & 15.63 & 1.24 & $0.003^{*}$ \\
& $18-39$ & 13.86 & 0.91 & 14.04 & 1.06 & 0.51 \\
& $40-59$ & 13.38 & 1.08 & 14.07 & 1.29 & 0.052 \\
C4 & $\geq 60$ & 15.12 & 1.45 & 14.01 & 1.22 & $0.002^{*}$ \\
& $18-39$ & 13.08 & 0.77 & 13.68 & 1.15 & $0.032^{*}$ \\
& $40-59$ & 12.94 & 1.08 & 13.50 & 1.07 & 0.07 \\
C5 & $\geq 60$ & 13.88 & 1.16 & 13.51 & 1.03 & 0.22 \\
& $18-39$ & 13.10 & 0.68 & 14.03 & 1.30 & $<0.001^{*}$ \\
& $40-59$ & 13.06 & 0.64 & 13.81 & 0.96 & $0.006^{*}$ \\
C6 & $\geq 60$ & 13.92 & 1.04 & 13.79 & 1.15 & 0.60 \\
& $18-39$ & 13.13 & 0.08 & 14.17 & 1.21 & $<0.001^{*}$ \\
& $40-59$ & 13.11 & 1.22 & 13.91 & 0.96 & $0.006^{*}$ \\
C7 & $\geq 60$ & 13.96 & 1.07 & 14.17 & 1.47 & 0.38 \\
& $18-39$ & 13.34 & 0.78 & 14.34 & 1.13 & $<0.001^{*}$ \\
& $40-59$ & 13.15 & 1.59 & 14.26 & 0.90 & $<0.001^{*}$ \\
& $\geq 60$ & 14.06 & 0.86 & 14.18 & 1.58 & 0.75 \\
\hline
\end{tabular}

$* \mathrm{p}$ value $<0.05$ was considered significant. 
MORALES-AVALOS, R.; MARTÍNEZ-GONZÁLEZ, B.; VILLARREAL-GARCIA, F. I.; REQUENA-ARAUJO, P. M.; MARTÍNEZ-GUTIÉRREZ, O. A.; REYES-FERNÁNDEZ, P. M.; PEÑA-MARTÍNEZ, V. M.; SÁNCHEZ-MEJORADA, G.; VÍLCHEZ-CAVAZOS, F.; GUZMÁN-LÓPEZ, S. \& ELIZONDO-OMAÑA, R. E. Variations in the Torg-Pavlov Cervical Ratio with regard to age and sex. a comprehensive anatomical and morphometric study on contemporary cadaveric specimens. Int. J. Morphol., 36(2):598-607, 2018.

nal was more variable between age groups and vertebral levels (Fig. 3).

The mean of the results for the AP diameter of the vertebral canal showed significant differences $(\mathrm{p} \leq 0.05)$ between men and women in most age groups and levels studied. (Table IV).

Table V Comparison of the anteroposterior diameter of the vertebral canal between age groups.

\begin{tabular}{cccc}
\hline Vertebral level & $\begin{array}{c}\text { Comparison by } \\
\text { age groups }\end{array}$ & $\begin{array}{c}\text { Women } \\
p \text { value }\end{array}$ & $\begin{array}{c}\text { Men } \\
p \text { value }\end{array}$ \\
\hline C2 & $18-39$ vs $40-59$ & 0.14 & NS $(0.38)$ \\
& $18-39$ vs $\geq 60$ & $<0.001^{*}$ & NS $(0.99)$ \\
& $40-59$ vs $\geq 60$ & 0.08 & 0.32 \\
C3 & $18-39$ vs $40-59$ & 0.12 & 0.91 \\
& $18-39$ vs $\geq 60$ & $<0.001^{*}$ & 0.90 \\
& $40-59$ vs $\geq 60$ & $<0.001^{*}$ & 0.83 \\
C4 & $18-39$ vs $40-59$ & 0.61 & 0.49 \\
& $18-39$ vs $\geq 60$ & $0.009^{*}$ & 0.52 \\
& $40-59$ vs $\geq 60$ & $0.011^{*}$ & 0.96 \\
C5 & $18-39$ vs $40-59$ & 0.22 & 0.40 \\
& $18-39$ vs $\geq 60$ & $<0.001^{*}$ & 0.41 \\
& $40-59$ vs $\geq 60$ & $0.004^{*}$ & 0.94 \\
C6 & $18-39$ vs $40-59$ & 0.85 & 0.31 \\
& $18-39$ vs $\geq 60$ & $0.01^{*}$ & 0.98 \\
& $40-59$ vs $\geq 60$ & $0.03^{*}$ & 0.36 \\
C7 & $18-39$ vs $40-59$ & 0.16 & 0.75 \\
& $18-39$ vs $\geq 60$ & $0.005^{*}$ & 0.60 \\
& $40-59$ vs $\geq 60$ & $0.002^{*}$ & 0.75
\end{tabular}

*p value $<0.05$ was considered significant.
Age Differences. Table V shows a comparing of the AP diameter of the vertebral canal by age for each studied sex. No significant differences were found between age groups in men in any of the vertebral levels. When comparing the groups 18-39 years and 40-59 years in women, against age group $\geq 60$ values were significantly higher in both cases (Table V).

\section{Torg-Pavlov ratio.}

General and intersegmental differences. Table VI shows the Torg-Pavlov ratio obtained at each level and for each age and sex. In Figure 4 is presented a graphic with the variations in the Torg-Pavlov ratio in each vertebral level by sex and age.

When calculating the Torg - Pavlov ratio, we found in the group of women 40-59 years a ratio < $0.8(0.74)$; this was at the $\mathrm{C} 6$ and $\mathrm{C} 7$ levels. Torg-Pavlov ratio decreased from C2 to $\mathrm{C} 7$ in all age groups and sexes studied (Table VI).

Sex Differences. The Torg-Pavlov ratios obtained were higher in women compared to men, this in all age groups and vertebral levels. Except in the group of 40-59 years at the C6 and C7 levels, which had lower values than men (Fig. 4).

The mean results for the Torg-Pavlov ratios showed significant differences $(\mathrm{p} \leq 0.05)$ between men and women in most age groups and levels (Table VI).

Table VI. Results of the Torg-Pavlov ratio for each age group and vertebral level. Comparison between sexes.

\begin{tabular}{ccccccc}
\hline & & \multicolumn{2}{c}{ Women $(\mathrm{n}=64)$} & \multicolumn{2}{c}{ Men $(\mathrm{n}=106)$} & Women vs Men \\
\hline Vertebral level & Age range (years) & Mean $(\mathrm{mm})$ & $\mathrm{SD}(\mathrm{mm})$ & Mean $(\mathrm{mm})$ & $\mathrm{SD}(\mathrm{mm})$ & $p$ value \\
\hline C2 & $18-39$ & 1.08 & 0.11 & 1.00 & 0.13 & $0.01^{*}$ \\
& $40-59$ & 1.11 & 0.16 & 0.95 & 0.12 & $<0.001^{*}$ \\
C3 & $\geq 60$ & 1.20 & 0.20 & 0.98 & 0.15 & $<0.001^{*}$ \\
& $18-39$ & 1.01 & 0.09 & 0.91 & 0.12 & $<0.001^{*}$ \\
& $40-59$ & 0.98 & 0.14 & 0.91 & 0.14 & $0.08^{*}$ \\
C4 & $\geq 60$ & 1.10 & 0.16 & 0.90 & 0.15 & $<0.001^{*}$ \\
& $18-39$ & 0.94 & 0.08 & 0.88 & 0.11 & $0.035^{*}$ \\
C5 & $40-59$ & 0.92 & 0.14 & 0.86 & 0.13 & 0.14 \\
& $\geq 60$ & 0.97 & 0.09 & 0.84 & 0.13 & $<0.001^{*}$ \\
C6 & $18-39$ & 0.91 & 0.09 & 0.89 & 0.13 & 0.57 \\
& $40-59$ & 0.87 & 0.07 & 0.85 & 0.11 & 0.44 \\
& $\geq 60$ & 0.94 & 0.07 & 0.82 & 0.11 & $<0.001^{*}$ \\
C7 & $18-39$ & 0.88 & 0.10 & 0.85 & 0.12 & 0.45 \\
& $40-59$ & 0.74 & 0.14 & 0.82 & 0.13 & 0.13 \\
& $\geq 60$ & 0.88 & 0.10 & 0.81 & 0.12 & $0.009^{*}$ \\
& $18-39$ & 0.87 & 0.11 & 0.84 & 0.10 & 0.20 \\
& $40-59$ & 0.74 & 0.19 & 0.80 & 0.11 & 0.08 \\
& $\geq 60$ & 0.89 & 0.08 & 0.80 & 0.14 & $0.02^{*}$ \\
\hline
\end{tabular}

$* \mathrm{p}$ value $<0.05$ was considered significant. 
MORALES-AVALOS, R.; MARTÍNEZ-GONZÁLEZ, B.; VILLARREAL-GARCIA, F. I.; REQUENA-ARAUJO, P. M.; MARTÍNEZ-GUTIÉRREZ, O. A.; REYES-FERNÁNDEZ, P. M.; PEÑA-MARTÍNEZ, V. M.; SÁNCHEZ-MEJORADA, G.; VÍLCHEZ-CAVAZOS, F.; GUZMÁN-LÓPEZ, S. \& ELIZONDO-OMAÑA, R. E. Variations in the Torg-Pavlov Cervical Ratio with regard to age and sex. a comprehensive anatomical and morphometric study on contemporary cadaveric specimens. Int. J. Morphol., 36(2):598-607, 2018.

Age Differences. Table VII shows a comparing of the TorgPavlov ratio by age for each studied sex. The results of the Torg-Pavlov ratio showed no significant difference between most age groups in each vertebral level and sex studied.

Table VII. Comparison of the Torg-Pavlov ratio between age groups.

\begin{tabular}{cccc}
\hline Vertebral level & $\begin{array}{c}\text { Comparison by } \\
\text { age groups }\end{array}$ & $\begin{array}{c}\text { Women } \\
\text { P value }\end{array}$ & $\begin{array}{c}\text { Men } \\
\text { P value }\end{array}$ \\
\hline \multirow{2}{*}{ C2 } & $18-39$ vs $40-59$ & 0.46 & 0.11 \\
& $18-39$ vs $\geq 60$ & $0.01^{*}$ & 0.60 \\
& $40-59$ vs $\geq 60$ & 0.12 & 0.37 \\
$18-39$ vs $40-59$ & 0.34 & 0.94 \\
C3 & $18-39$ vs $\geq 60$ & $0.02^{*}$ & 0.73 \\
& $40-59$ vs $\geq 60$ & $0.01^{*}$ & 0.79 \\
C4 & $18-39$ vs $40-59$ & 0.55 & 0.52 \\
& $18-39$ vs $\geq 60$ & 0.11 & 0.21 \\
& $40-59$ vs $\geq 60$ & 0.10 & 0.56 \\
C5 & $18-39$ vs $40-59$ & 0.19 & 0.19 \\
& $18-39$ vs $\geq 60$ & 0.21 & $0.03 *$ \\
& $40-59$ vs $\geq 60$ & $0.006^{*}$ & 0.33 \\
C6 & $18-39$ vs $40-59$ & $<0.001^{*}$ & 0.053 \\
& $18-39$ vs $\geq 60$ & 0.78 & 0.06 \\
& $40-59$ vs $\geq 60$ & $<0.001^{*}$ & $0.89)$ \\
C7 & $18-39$ vs $40-59$ & $0.007^{*}$ & 0.25 \\
& $18-39$ vs $\geq 60$ & 0.45 & 0.46 \\
& $40-59$ vs $\geq 60$ & $<0.001^{*}$ & 0.80 \\
\hline
\end{tabular}

Women generally showed more cases where the Torg-Pavlov ratio differed significantly $(\mathrm{p} \leq 0.05)$ between age groups for most of the studied vertebral levels (C2, C3 and C5-C7) (Table VII).

\section{DISCUSSION}

This study reports the normal values of the AP diameter of the vertebral body, the AP diameter of the vertebral canal and the Torg-Pavlov ratio of 1020 cervical vertebrae at each level (C2-C7). The relevance is that it determines for the first time the variations of the Torg- Pavlov ratio by sex and age in a big sample of normal bone specimens.

\section{AP diameter of the vertebral body}

General and intersegmental differences. The vertebral bodies of the cervical vertebrae have been studied by various authors to assess the Torg-Pavlov ratio (Malzac \& Barros Filho, 2002; Ishikawa et al., 2003; Lim \& Wong; Karabulut \& Karabulut, 2007). Its importance lies precisely in its usefulness to confirm or exclude the diagnosis of cervical spinal canal stenosis when combined with the diameter of the cervical canal (Pavlov et al.).

$*$ p value $<0.05$ was considered significant.

\section{TORG-PAVLOV RATIO}

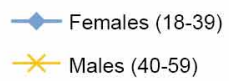

- Females (18-39
$\times$ Males (40-59)

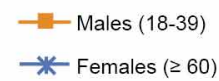

- Females (40-59)

- Males $(\geq 60)$

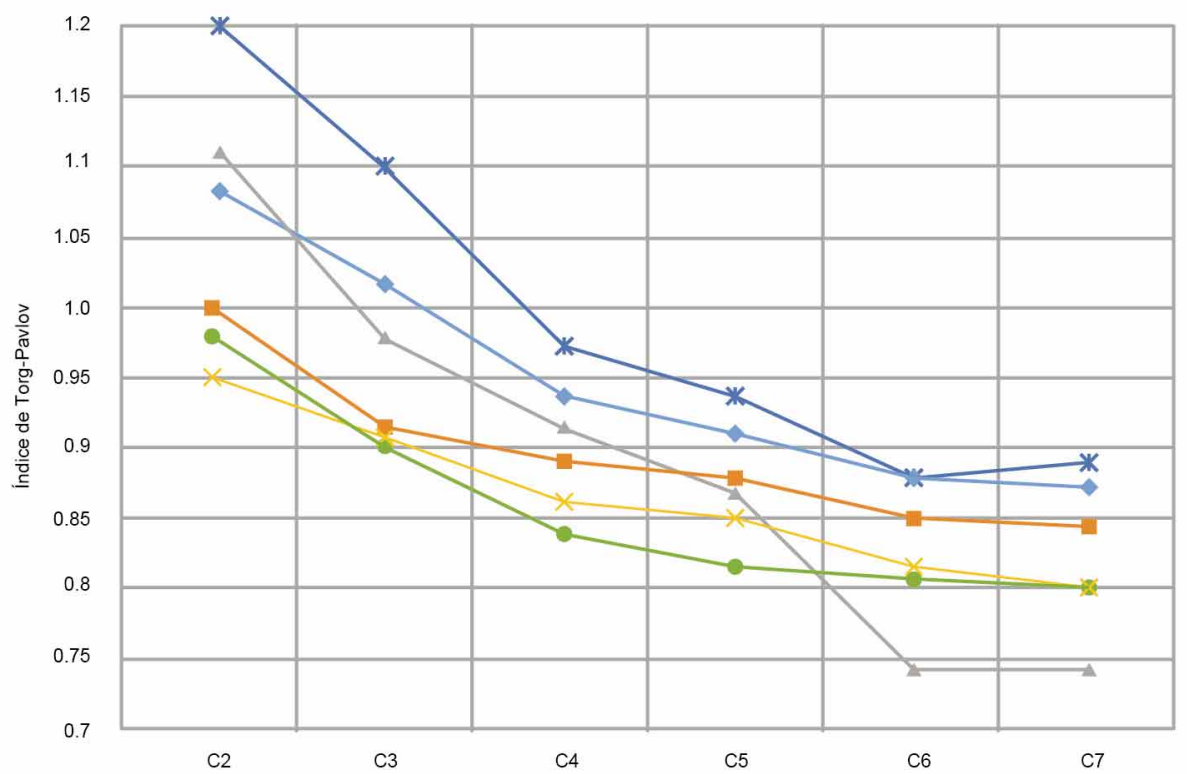

Fig. 4. Variations in the Torg-Pavlov ratio (C2-C7) by sex and age group. 
MORALES-AVALOS, R.; MARTÍNEZ-GONZÁLEZ, B.; VILLARREAL-GARCIA, F. I.; REQUENA-ARAUJO, P. M.; MARTÍNEZ-GUTIÉRREZ, O. A.; REYES-FERNÁNDEZ, P. M.; PEÑA-MARTÍNEZ, V. M.; SÁNCHEZ-MEJORADA, G.; VÍLCHEZ-CAVAZOS, F.; GUZMÁN-LÓPEZ, S. \& ELIZONDO-OMAÑA, R. E. Variations in the Torg-Pavlov Cervical Ratio with regard to age and sex. a comprehensive anatomical and morphometric study on contemporary cadaveric specimens. Int. J. Morphol., 36(2):598-607, 2018.

In our study, we found that both in men and women and in all age groups, the AP diameter of the vertebral body descends from $\mathrm{C} 2$ to $\mathrm{C} 3$ and subsequently undergoes an increase from $\mathrm{C} 4$ to $\mathrm{C} 7$ (Fig. 2). This can be explained by the amount of force that each vertebral body must support, as well as the physiological curvature of the vertebral column.

Sex differences. Sexual dimorphism of the vertebral body of the cervical spine described by several authors was confirmed in our study (Liguoro et al., 1994; Lim \& Wong; Matveeva et al.; Karabulut \& Karabulut), where it is mentioned that it is greater in men than in women. These might be the definitive behavior of this parameter.

These morphometric differences between men and women may be attributed to factors that vary in the sexes, such as: Physiological and endocrine changes, nutrition, the amount and intensity of physical activity in different stages of life and osteodegenerative changes (Guggenbuhl, 2009; Gielen et al., 2011; Morales-Avalos et al.). Besides, as in women, men also lose bone mass and density, however, on average, this begins 10 or 15 years after it does in women. This is why they have a greater bone density and therefore bigger bones than women (Guggenbuhl; Gielen et al.; Morales-Avalos et al.).

Age Differences. There is little evidence in the literature regarding differences in the AP diameter of the vertebral bodies with respect to age, because this parameter has not been studied by age group.

We found that in men the AP diameter of the vertebral body tends to increase with age. While in women it increases from 18 to 59 years and finally it decreases in $\geq 60$ years (Fig. 2). This behavior in women less than 60 years, may be presented because during this stage of life, bones maintain stable their structure and composition. This is due to the osteoblastic regeneration and the bone remodeling by estrogens during this period (Morales-Avalos et al.).

As age increases, according to previous studies, the AP diameter of the vertebral body decreases (Liguoro et al.). This was not observed in our study. This difference can be explained because previous studies do not differentiate by age groups (Liguoro et al.; Karabulut \& Karabulut; Lim \& Wong; Malzac \& Barros Filho), as we did in our study, where this diminish in the AP diameter of the vertebral body was only observed in women $\geq 60$ years (Fig. 2).

\section{AP diameter of the vertebral canal.}

General and intersegmental differences. In our study the AP diameter of the vertebral canal in men and women in every age group diminished from $\mathrm{C} 2$ to $\mathrm{C} 4$ and increased from C5 to C7 (Figure 3). This is similar to what other studies reported in most healthy populations (Switzerland, Japan, Macedonia, Africa, and America) (Pavlov et al.; Aebli et al.; Tatarek; Karabulut \& Karabulut; Kato et al., 2012; Matveeva et al.; Yukawa et al., 2012; Nagata et al., 2014).

In our study, the diameter of the spinal canal was greater in C2 (Fig. 3), which is consistent with previous studies (Karabulut \& Karabulut; Lim \& Wong; Tatarek; Yukawa et al.). This can also be attributed to the larger spinal cord at this level (Aebli et al.). Although other authors have found that there is no relationship between cord diameter and cervical canal (Ishikawa et al.).

During flexion and extension, the spinal cord elongates and shortens, respectively. So as C4 is the site of the smallest diameter of the cervical canal this movements increase the risk of pinching (Reid, 1960). In the literature, C4 - C5 is the place where acute spinal cord injury is most often reported after minor trauma (Lim \& Wong; Malzac \& Barros Filho; Matta Ibarra et al., 2007).

Sex differences. We found that the vertebral canal is greater in men than in women in most age groups and levels studied (Fig. 3). This is similar to that reported in other studies (Dean et al.; Lee et al., 2007; Yukawa et al.). The osseous elements of the vertebral column maintain a proportion in their dimensions between its anterior and posterior components. So, it is logical that the AP diameter of the vertebral canal behaves similarly to the vertebral body. This is corroborated in our study.

However, we found that in women $\geq 60$ years, the C2 to C5 levels had greater diameters than men (Fig. 3). This can be explained due to a decrease in the AP diameter of the vertebral body observed in this age group.

Age differences. We found that the size of the vertebral canal in men was highly variable between age groups. However, in women, there was a decrease in the size of the canal from the 18-59 and finally an increase in size in the $\geq$ 60 years group (Fig. 3). Although previous studies report that the diameter of the cervical canal decreases as age increases (Ishikawa et al.; Meyer et al., 2008; Kato et al.; Yukawa et al.), in our study we showed that this happens at 60 years in women and in men only in the C5 and C7 levels.

The significant difference observed for most of the age groups in females (Table V), can be explained by the estrogen changes that occur in women throughout the different stages of their lives (Morales-Avalos et al.). This is corroborated by the findings in men, where cases with 
MORALES-AVALOS, R.; MARTÍNEZ-GONZÁLEZ, B.; VILLARREAL-GARCIA, F. I.; REQUENA-ARAUJO, P. M.; MARTÍNEZ-GUTIÉRREZ, O. A.; REYES-FERNÁNDEZ, P. M.; PEÑA-MARTÍNEZ, V. M.; SÁNCHEZ-MEJORADA, G.; VíLCHEZ-CAVAZOS, F.; GUZMÁN-LÓPEZ, S. \& ELIZONDO-OMAÑA, R. E. Variations in the Torg-Pavlov Cervical Ratio with regard to age and sex. a comprehensive anatomical and morphometric study on contemporary cadaveric specimens. Int. J. Morphol., 36(2):598-607, 2018.

significant differences were not observed (Table V). So that we conclude that in men the vertebral canal maintains its dimensions during life without suffering significant changes.

\section{Torg-Pavlov ratio .}

General and intersegmental differences. The Torg- Pavlov ratio is used for the diagnosis of cervical canal stenosis (Aebli et al.). Its calculation consists of a division between the AP diameter of the cervical canal and the AP diameter of the cervical vertebral body (Pavlov et al.). All data obtained in our study were similar to those obtained in previous studies (Aebli et al.; Blackley et al., 1999; Ishikawa et al.; Karabulut \& Karabulut; Lim \& Wong; Malzac \& Barros Filho; Pavlov et al.; Suk et al., 2009; Nagata et al.; Matveeva et al.; Tjahjadi $\&$ Onibala). However, in our study, besides evaluating the vertebral body and the vertebral canal for each vertebral level, we made a comparison between age groups and sex.

Both men and women in all age groups and at all vertebral levels studied had a decreased Torg-Pavlov ratio from C2 to C7 (Figure 4), as reported, in Swiss (Aebli et al.), Turkish (Karabulut \& Karabulut), New Yorker (Pavlov et al.), Canadian and New Zealander (Blackley et al.) populations.

Sex differences. The Torg-Pavlov ratio was lower in men than in women in all age groups and vertebral levels (Fig. 4). Our data match with the reported by other authors (Ishikawa et al.; Lim \& Wong; Matveeva et al.; Nagata et al.; Pavlov et al.; Tjahjadi \& Onibala). Matveeva et al. explains that this is because the vertebral body is larger in men than in women. They also reported that the vertebral body highly influences over the variations observed in the Torg-Pavlov ratio (Matveeva et al.). We partially agree with their conclusion, because in our opinion, the age influence in greater proportion the Torg-Pavlov ratio, and this variable was not considered in their study.

That the Torg-Pavlov ratio be lower in men than in women, as observed in our study, is important because the higher prevalence of stenosis of the cervical canal in men is related to a higher prevalence of cervical myelopathy in this sex (Nagata et al.).

Age differences. We found that in men the Torg-Pavlov ratio decreases with age. While in women it decreased from 18 to 59 years and then increased in the $\geq 60$ years group (Fig. 4). This is explained by the behavior that has the vertebral body in the different age groups.

In general, there was no significant difference between most age groups in each sex (Table VII). This result is similar to that reported in the study by Nagata et al., in which the age differences in the cervical canal were evaluated in 959 Japanese using radiographs and magnetic resonance. This was the only study found in the literature in which the Torg-Pavlov ratio was evaluated by age and groups and no significant differences were found between them (Nagata et al.). Besides, in this study a decrease in the Torg-Pavlov ratio with age was reported (Nagata et al.), as we found in our study.

Regarding age, in women there were a higher number of cases in which the Torg-Pavlov ratio was significantly different (Table VII). This is because in women, both the vertebral body and the vertebral canal showed more frequently significant differences regarding age (compared with men), being these differences higher in the vertebral canal (Table III and V). So that we think that in women the Torg-Pavlov ratio is highly determined by the variations in the vertebral canal.

In conclusion, this study reports quantitatively differences in the morphometric characteristics of the AP diameter of the vertebral body, the vertebral canal and the TorgPavlov ratio by sex and age in a big sample of contemporary bone specimens. The results obtained in this study will serve as a basis for basic and clinic subsequent studies that aim to correlate the onset of clinical symptoms with the dimensions of the cervical elements.

This study concludes, that in men the Torg-Pavlov ratio is determined both by the vertebral body and the vertebral canal, because there were no variations in these two parameters for most of the age groups. While in women the Torg-Pavlov ratio is highly determined by the vertebral canal, because this parameter presented more variability between the different age groups.

ACKNOWLEDGEMENTS. We thank the anthropologist, Guillermo Torres for the technical help provided for this study and Sergio Lozano-Rodriguez, M.D. for his help in translating the manuscript.

MORALES-AVALOS, R.; MARTÍNEZ-GONZÁLEZ, B.; VILLARREAL-GARCIA, F. I.; REQUENA-ARAUJO, P. M.; MARTÍNEZ-GUTIÉRREZ, O. A.; REYES-FERNÁNDEZ, P. M.; PEÑA-MARTÍNEZ, V. M.; SÁNCHEZ-MEJORADA, G.; VÍLCHEZ-CAVAZOS，F.; GUZMÁN-LÓPEZ，S. \& ELIZONDO-OMAÑA, R. E. Variaciones en el índice de TorgPavlov cervical respecto a edad y sexo. Un exhaustivo estudio anatómico en una población contemporánea. Int. J. Morphol., 36(2) :598-607, 2018

RESUMEN: El Índice de Torg-Pavlov se utiliza para la detección de estenosis del canal cervical. Un resultado $\leq 0.80$ indica estenosis significativa. Se obtiene dividiendo el diámetro anteroposterior del canal cervical entre el diámetro anteroposterior 
del cuerpo. El objetivo de este estudio fue evaluar estos parámetros y determinar si existen diferencias significativas en relación con el sexo y la edad. Se realizó un estudio anatómico y comparativo, en el que se incluyeron 1020 vértebras cervicales de C2-C7 tomadas de una colección osteológica. Se determinó el diámetro anteroposterior del cuerpo vertebral, el diámetro anteroposterior del canal vertebral y el Índice de Torg-Pavlov. Las piezas evaluadas se dividieron en grupos de acuerdo al sexo y la edad, resultando en seis grupos de estudio. Se realizó un análisis estadístico para determinar si existían diferencias significativas entre estos grupos. El tamaño del cuerpo vertebral disminuyó de C2-C3 y aumentó de C4-C7. El canal disminuyó de C2-C4 y aumentó de C5-C7. El Índice de Torg-Pavlov disminuyó de C2-C7. El cuerpo y el canal vertebral fueron mayores en los hombres, mientras que el Índice de Torg-Pavlov fue mayor en las mujeres. Con la edad, en los hombres, el tamaño del cuerpo vertebral aumentó, el canal mantuvo su tamaño y el Índice de Torg-Pavlov disminuyo significativamente. En el grupo de mujeres $\geq 60$ años, el tamaño del cuerpo disminuyó y el canal y el Índice de Torg-Pavlov aumentaron. En los hombres, el tamaño del cuerpo y el canal vertebral determinan el Índice de Torg-Pavlov, ya que estos no mostraron diferencias en la mayoría de los grupos de edad. Mientras que, en las mujeres, este está determinado principalmente, por el canal vertebral, porque este parámetro presento más variabilidad entre los grupos de edad.

PALABRAS CLAVE: Estenosis cervical; Vértebras cervicales; Canal espinal; Grupos de edad; Sexo.

\section{REFERENCES}

Aebli, N.; Wicki, A. G.; Rüegg, T. B.; Petrou, N.; Eisenlohr, H. \& Krebs, J. The Torg-Pavlov ratio for the prediction of acute spinal cord injury after a minor trauma to the cervical spine. Spine J., 13(6):605-12, 2013.

Blackley, H. R.; Plank, L. D. \& Robertson, P. A. Determining the sagittal dimensions of the canal of the cervical spine. The reliability of ratios of anatomical measurements. J. Bone Joint Surg. Br., 81(1):110-2, 1999.

Castro, F. P. Jr. Stingers, cervical cord neurapraxia, and stenosis. Clin. Sports Med., 22(3):483-92, 2003

Dean, C. L.; Lee, M. J. \& Cassinelli, E. H. Incidence of cervical stenosis: Radiographic and anatomic. Semin. Spine Surg., 19(1):12-7, 2007.

Gielen, E.; Vanderschueren, D.; Callewaert, F. \& Boonen, S. Osteoporosis in men. Best Pract. Res. Clin. Endocrinol. Metab., 25(2):321-35, 2011.

Guggenbuhl, P. Osteoporosis in males and females: Is there really a difference? Joint Bone Spine, 76(6):595-601, 2009.

Ishikawa, M.; Matsumoto, M.; Fujimura, Y.; Chiba, K. \& Toyama, Y. Changes of cervical spinal cord and cervical spinal canal with age in asymptomatic subjects. Spinal Cord., 41(3):159-63, 2003.

Karabulut, Ö. \& Karabulut, Z. The variations of Torg ratio with sex in patients with neck pain. Dicle Tip Derg., 34(4):272-4, 2007.

Kato, F.; Yukawa, Y.; Suda, K.; Yamagata, M. \& Ueta, T. Normal morphology, age-related changes and abnormal findings of the cervical spine. Part II: Magnetic resonance imaging of over 1,200 asymptomatic subjects. Eur. Spine J., 21(8):1499-507, 2012.

Lee, M. J.; Cassinelli, E. H. \& Riew, K. D. Prevalence of cervical spine stenosis. Anatomic study in cadavers. J. Bone Joint Surg. Am., 89(2):376-80, 2007.

Liguoro, D.; Vandermeersch, B. \& Guérin, J. Dimensions of cervical vertebral bodies according to age and sex. Surg. Radiol. Anat., 16(2):149$55,1994$.
Lim, J. K. \& Wong, H. K. Variation of the cervical spinal Torg ratio with sex and ethnicity. Spine J., 4(4):396-401, 2004.

Malzac, A. \& Barros Filho, T. E. P. Morfometria do canal vertebral no segmento cervical em militares jovens assintomáticos. Acta Ortop. Bras., 10(4):40-51, 2002.

Matta Ibarra, J.; Jaimes Sepúlveda, L. \& Corredor Baldeón, C. Estenosis cervical: descompresión, fijación y artrodesis vía anterior. Rev. Colomb. Ortop. Traumatol., 21(4):225-31, 2007.

Matveeva, N.; Janevski, P.; Nakeva, N.; Zhivadinovik, J. \& Dodevski, A. Morphometric analysis of the cervical spinal canal on MRI. Pril. (Makedon Akad Nauk Umet Odd Med Nauki), 34(2):97-103, 2013.

Meyer, F.; Börm, W. \& Thomé, C. Degenerative cervical spinal stenosis: current strategies in diagnosis and treatment. Dtsch. Arztebl. Int., 105(20):366-72, 2008.

Morales-Avalos, R.; Leyva-Villegas, J.; Sánchez-Mejorada, G.; CárdenasSerna, M.; Vílchez-Cavazos, F.; Martínez-Ponce De León, A.; ElizondoRiojas, G.; Martínez-García, J.; De La Garza-Castro, O.; ElizondoOmaña, R. \& Guzmán-López, S. Age- and sex-related variations in morphometric characteristics of thoracic spine pedicle: A study of 4,800 pedicles. Clin. Anat., 27(3):441-50, 2013.

Nagata, K.; Yoshimura, N.; Hashizume, H.; Muraki, S.; Ishimoto, Y.; Yamada, H.; Takiguchi, N.; Nakagawa, Y.; Minamide, A.; Oka, H.; Kawaguchi, H.; Nakamura, K.; Akune, T. \& Yoshida, M. The prevalence of cervical myelopathy among subjects with narrow cervical spinal canal in a population-based magnetic resonance imaging study: the Wakayama Spine Study. Spine J., 14(12):2811-7, 2014.

Pavlov, H.; Torg, J. S.; Robie, B. \& Jahre, C. Cervical spinal stenosis: determination with vertebral body ratio method. Radiology, 164(3):7715, 1987.

Reid, J. D. Effects of flexion-extension movements of the head and spine upon the spinal cord and nerve roots. J. Neurol. Neurosurg. Psychiatry, 23(3):214-21, 1960.

Suk, K. S.; Kim, K. T.; Lee, J. H.; Lee, S. H.; Kim, J. S. \& Kim, J. Y. Reevaluation of the Pavlov ratio in patients with cervical myelopathy. Clin. Orthop. Surg., 1(1):6-10, 2009.

Tatarek, N. E. Variation in the human cervical neural canal. Spine J., 5(6):623-31, 2005.

Tierney, R. T.; Maldjian, C.; Mattacola, C. G.; Straub, S. J. \& Sitler, M. R. Cervical spine stenosis measures in normal subjects. J. Athl. Train., 37(2):190-3, 2002.

Tjahjadi, D. \& Onibala, M. Z. Torg ratios based on cervical lateral plain films in normal subjects. Universa Med., 29(1):8-13, 2010.

Yukawa, Y.; Kato, F.; Suda, K.; Yamagata, M. \& Ueta, T. Age-related changes in osseous anatomy, alignment, and range of motion of the cervical spine. Part I: Radiographic data from over 1,200 asymptomatic subjects. Eur. Spine J., 21(8):1492-8, 2012.

\section{Corresponding author:}

Dr. Rodolfo Morales-Avalos

Servicio de Ortopedia y Traumatología

Hospital Universitario "Dr. José Eleuterio González"

Universidad Autónoma de Nuevo León (U.A.N.L.)

Ave. Francisco I. Madero s/n Col. Mitras Centro

Monterrey, Nuevo León

MÉXICO

E-mail: rodolfot59@hotmail.com

Received: 28-10-2017

Accepted: 19-12-2017 